\title{
Energetic Implications of a Post-industrial Information Economy: The Case Study of Australia
}

\author{
Graham Palmer ${ }^{1}$
}

Received: 29 August 2016 / Accepted: 28 March 2017 / Published online: 4 April 2017

(C) Springer International Publishing Switzerland 2017

\begin{abstract}
The potential for decoupling of energy and resources from economic growth should enable economic development while improving environmental sustainability indicators. Relative decoupling of energy has been a characteristic of developed nations as a consequence of efficiency gains and productivity growth. The trend has strengthened in recent decades as economies have advanced further into the service economy phase. The next phase of development (the so-called 'Infotronics' phase) is being enabled by the rapid growth of information and communications technology (ICT), and artificial intelligence. The question explored in this commentary is whether the Infotronics phase will shift energy consumption in absolute rather than relative terms (so-called 'strong' vs. 'weak' decoupling), using Australia as a case study. In this context, weak decoupling is defined as a relative reduction in energy consumption per unit of GDP, whereas strong decoupling is also an absolute reduction in national energy consumption. Historic data on Australian primary energy consumption, gross domestic product, GDP deflator, and industrial sectors have been assembled for the period 1900-2014. A time-series linear regression between energy and real GDP was undertaken to explore the historic relationship between changes in the changing structure of the Australian economy and energy consumption. Despite a significant shift towards a service economy, primary energy consumption has remained strongly connected to GDP, but overlaid with distinct long-run trends in energy intensity.
\end{abstract}

Graham Palmer

graham.palmer@climate-energy-college.org;

graham@paltech.com.au

1 Australian-German College of Energy and Climate, The University of Melbourne, Melbourne, Australia
An explanation for the long-run connection is two-fold. The evolution towards greater social and industrial complexity has been underpinned by the ready availability of cheap fuels. The deepening of the service economy towards the infotronics phase should be seen partly as a consequence of available energy supply and productive primary and secondary sectors. Several specific examples of ICT are explored to test the hypothesis, including ICT-enabled remote work, online retail, the 'sharing economy', and productivity-enhancing ICT applications. Second, energy consumption is driven by demand for end-use energy services, including transport, buildings and food. Demand for these services is a function of human wants, needs and income, and a changing industrial structure does not alter their underlying demand. The conclusion is that ICT is enabling productivity gains and new business models, but does not significantly weaken the demand for these services, and therefore does not enable strong decoupling.

\section{ICT-Enabled Remote Work}

The increasing role of ICT-driven service sectors should, in principle, offer opportunities to enable 'strong' decoupling by substituting ICT for real-world interactions. Australian service sectors have a much lower energy intensity (energy consumed per dollar of value added) than the primary and secondary sectors, including agriculture, mining, manufacturing and transport (Stanwix et al. 2015). To the extent that ICT-enabled services can substitute for higher energy intensity products, energy consumption should be reduced, both in relative and absolute terms.

The case of ICT substituting for travel is one such example-passenger road transport makes up 40\% of Australia's transportation energy (Energy Information Agency (EIA) 
2015). Indeed, the example of communications-enabled decoupling has historic precedents-the eighteenth century telegraph, later telephone, transatlantic cable, right up to the late twentieth century internet are cases in which it was hypothesised that advanced communications would substitute for travel (Mokhtarian 2009).

However despite early optimism for ICT-enabled remote work, the substitution effect has not been as evident as originally assumed (Van Wee et al. 2013). Email and video conferencing has not been able to fully compensate for the richness of face-to-face contact, and the collegiality of a regular work group. Whatever reduction in travel that might have been expected from remote work has been overwhelmed by the economic growth enabled by ICT. By lowering the relative cost of information gathering, processing and enabling complementary business innovations, ICT has in fact provided a direct stimulant to business (Brynjolfsson and Hitt 2000). The expansion of ICT has occurred at the same time as rising travel congestion-Australian metropolitan travel distance tripled from 1970 to 2014 (Bureau of Infrastructure Transport and Regional Economics 2016, Fig. 1), while the population doubled.

\section{ICT and the Sharing Economy}

The emergence of 'sharing economy' applications, such as Uber, Lyft and Airbnb, provide examples in which software is impinging on real-world activities. Andreessen (2011) describes the foray of software into the physical world as 'software eating the world'. Once again, the substitution of low energy intensity software development, defined in the Australian National Accounts (Australian Bureau of Statistics (ABS) 2016a) as a low energy intensity service sector, seems to present a pathway of low energy development.

However, the significance of ICT seems to be more reflective of a business model disruption than a fundamental change to the physical and energetic outcomes. For example, Uber has been shown to have a higher utilisation factor than traditional taxis (Cramer and Krueger 2015). Nonetheless, the Uber service consists of conventional vehicles being driven on public roads, consuming the same public infrastructure and energy as conventional vehicles, albeit possibly at a slightly higher passenger-km efficiency. In Australia, Uber was estimated to have provided $6 \%$ of taxi industry rides during 2015, with strong continuing growth (Deloitte 2016). The Australian experience is that Uber is drawing in consumers who may not have otherwise taken a cab, and in some cases is substituting for travel modes that would have carried a lower energy intensity (energy per $\mathrm{km}$ ), such as trains. Similarly, in principle, Airbnb should be substituting for hotel rooms and increasing the utilisation of the built environment (i.e. fewer hotels would need to be constructed). However, Airbnb mainly competes in the more price-elastic leisure market, which has less impact on the established hotel market (Moody's 2016). Schor (2016) makes the observation that the productivity growth of sharing economy businesses will lead to macroeconomic growth effects that may overwhelm energy reduction effects.

\section{Dematerialization Driven by ICT}

An early version of dematerialization was Buckminster Fuller's concept of 'Ephemeralization'-doing more and more with less and less until eventually you can do everything with nothing (Fuller 1973, pp. 252-259). In a contemporary ICT-based version, Kurzweil (1999) hypothesised that computing power will eventually cross a critical boundary (the so-called singularity), after which dematerialized economic growth will accelerate sharply. Kurzweil (1999, p. 124) argued that there is a rapidly increasing knowledge and information content in products and services, and that these are not constrained by material resources.

Using Fuller as a backdrop, Lee (2011) uses the concrete example of the introduction of Google Maps onto smartphones to argue that information technology is a 'magic wand' that 'in one stroke, transformed millions of Android phones into sophisticated navigation devices'. In Lee's conception, the smartphone is assumed to be a low energy footprint device that substitutes for a host of real-world products-at zero marginal cost, Google Maps is said to be substituting for paper maps and dedicated navigation devices.

But the reverse is true-Nokia, Google and Apple all have multi-billion dollar 'real world' investments in mapping hardware, software development and data. Furthermore, GPS piggy backs onto the large sunk investment of the Navstar GPS satellite system. Google has bundled 'free' maps to improve the perceived value of Android, from which it reportedly made $\$ 31$ billion in revenue and $\$ 22$ billion in profit during the past seven years (Curry 2016). Furthermore, GPS devices are penetrating cameras and fitness devices, far exceeding the material and energy footprint of paper-based maps and atlases. Hence far from dematerialising, the 'magic' of GPS-enabled devices carries a far reaching energy and material footprint.

Smil (2013) provides a similar example in which apparent ICT dematerialisation has contributed to system growth effects that exceed the direct energy and resource-saving effects. The introduction of computer-aided design (CAD) and machining significantly reduced the man-hours and office infrastructure to produce a drawing and then produce the final product. But in a sort of rebound effect, 
CAD enabled orders-of-magnitude greater complexity and sophistication of advanced products, such as jetliners. Furthermore, the ease of translating ideas into products has contributed to an overwhelming diversity and choice of consumer and industrial products. Rather than dematerializing, CAD is better described as a complex form of material substitution.

The emergence of online retail demonstrates the multifaceted effects of ICT that may be difficult to quantify. For example, online women's fashion has grown at $15 \%$ in recent years in Australia (Magner 2016b), at the same time as the emergence of 'fast fashion', which has grown at $12 \%$ (Magner 2016a). Yet despite strong online growth, Australian suburban shopping malls continue with major redevelopment projects (Zhou and Robb 2016). A part explanation is that women's fashion is being driven by social media and online shopping, exposing consumers to the latest designer fashions (Magner 2016a). Furthermore, the environmental implications of online versus conventional shopping can be difficult to estimate when a broader perspective of shopper behaviour is considered (Edwards et al. 2010).

All of these examples illustrate the inter-relationships between growing complexity, a deepening of service sectors, energy consumption, and ICT. At face value, ICT applications may seem to represent low marginal cost, dematerialized solutions, but are in fact examples of Tainter's (1990) energy-complexity spiral in which software is embedded in an increasingly complex system with a far reaching energy footprint.

\section{The Energy Intensity of Australia's Economy}

The hypothesis that ICT is not leading to 'strong' decoupling was explored with the case study of Australia. Real GDP was derived by dividing nominal GDP by the GDP deflator. Primary energy consumption refers to the consumption of primary feedstock fuels for end-use consumption and electricity generation. In the case of electricity derived from renewable fuels, there are two alternative methods to calculate their primary energy equivalent. This commentary uses the IEA methodology, which simply assumes that $1 \mathrm{MJ}$ of electricity from hydro or renewables is equivalent to $1 \mathrm{MJ}$ of primary fuels (Modahl et al. 2013). The alternative method adopted by the EIA is to multiply the electricity generation by three to approximate the fuels that would otherwise have been combusted if the electricity was derived from coal, gas or petroleum. With a rising penetration of renewable fuels, the IEA method will tend to indicate greater decoupling (i.e. one unit of renewable electricity substitutes for three units of coal or gas).

Figure 1 compares the Australian real GDP and the primary energy consumption for the period 1900-2014. Over the period, the per capita real GDP increased 5.7-fold, and the per capita primary energy rose 7.6-fold. Viewed over a century, the primary energy consumption has been strongly connected to the gross domestic product, despite a strong shift towards a service economy (see Fig. 2). A time-series linear regression between real GDP as independent and primary energy as the dependent variable, with 115 annual observations, results in an $R$-squared of 0.973 , providing support for a correlation.

A closer inspection of the regression residuals reveals four phases. In the 'agrarian' phase up to around 1920, energy consumption rises faster than GDP, reflecting the substitution of labour with capital and energy to increase the productivity and output of agriculture and an emerging manufacturing sector. In the 'urbanisation' phase in the lead-up to the second world war and including the Great Depression, energy intensity remains constant. This marks a period of electricity substituting for steam power-the proportion of factory horsepower in Australia delivered by electricity had increased from $24 \%$ in 1918 , to $81 \%$ in 1939 (Australian Bureau of Statistics (ABS) 1920, 1940).

In the 'post-war industrialization' phase, tariff barriers support energy-intensive manufacturing, with energy intensity rising (Fig.3). Following the war, the chemical, electrical, automotive and iron and steel industries were seen as important national industries, and the motor car became a symbol of modernity and affluence (Frost and Dingle 1995).

This marks a period of expanding and growing house size in the major cities and commensurate expansion of car use. In 1945, there were only 0.12 motor vehicles per person, rising threefold to 0.36 by 1968 (Frost and Dingle 1995, p. 34). Passenger vehicles per capita rose linearly until an inflection in the 1980s led to slowing trend growth (Fig. 4). The post-war spread of Australian cities up until the 1990s exceeded one million hectares (Buxton 2006). New detached housing floor area rose steadily before peaking in 2008/09 (Commsec 2016). Near-complete electrification wasn't reached until around 1970 (Australian Bureau of Statistics (ABS) 1970), and for the period 1945 to 1970, national electricity consumption rose seven fold. By 1973, manufacturing consumed $38 \%$ of total primary energy. Electricity consumption continued to rise before moderating post-2010.

In the current 'service economy' phase, energy intensity is falling, reflecting the de-industrialisation of the economy due to structural changes starting in the 1980s, and ongoing efficiency gains (Stanwix et al. 2015). Household energy consumption has stabilised, with rising building and appliance efficiency being offset by rebound factors. In an engineering energy study, Palmer (2012) showed that despite significant and sustained improvements in appliance and building fabric 


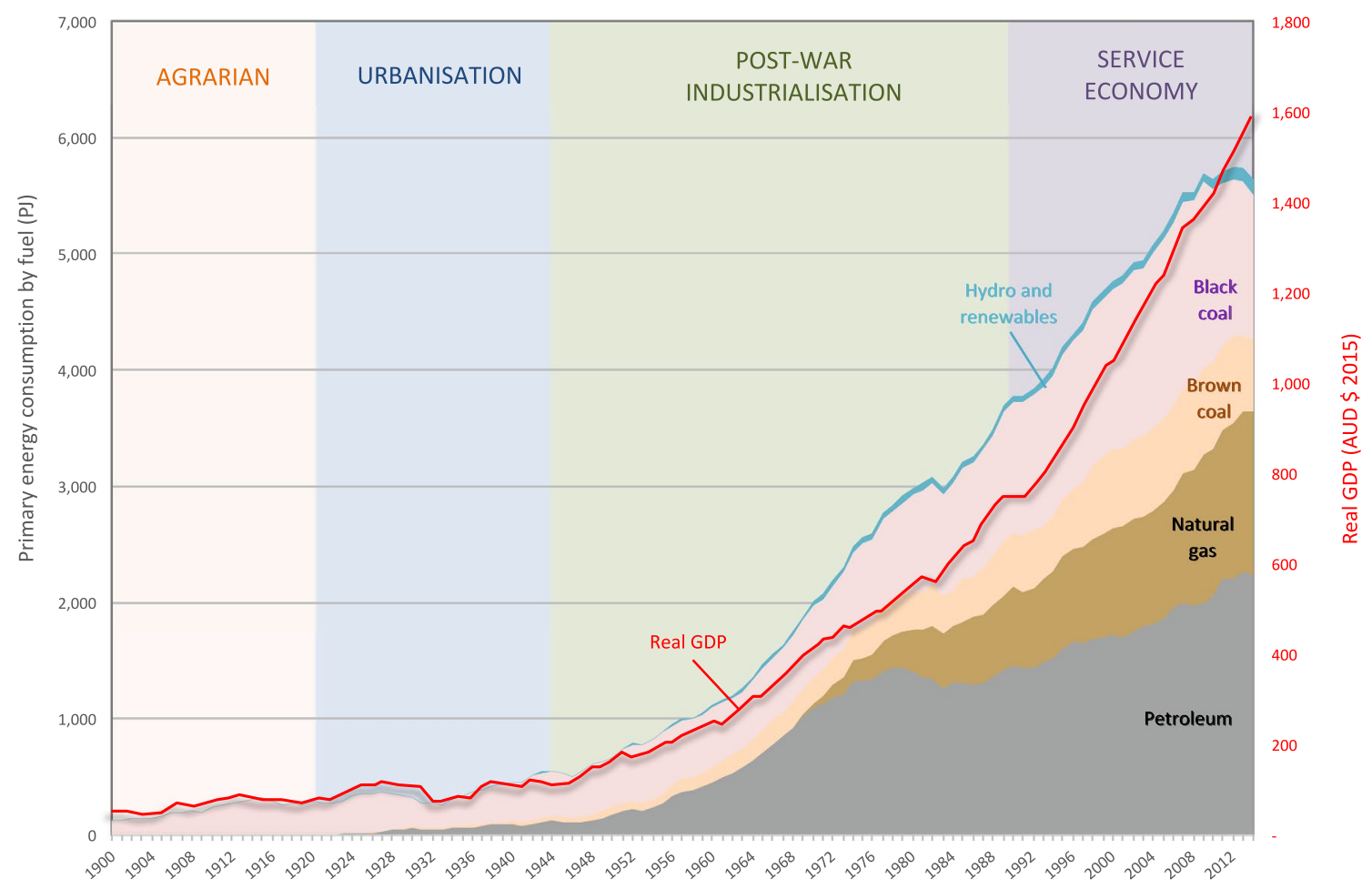

Fig. 1 Australia primary energy consumption and real GDP 1900-2014. Sources: Australian Bureau of Statistics (ABS) (2015a); Butlin (1962); Dyster and Meredith (1990); Office of the Chief Economist (2015); Vamplew (1987)

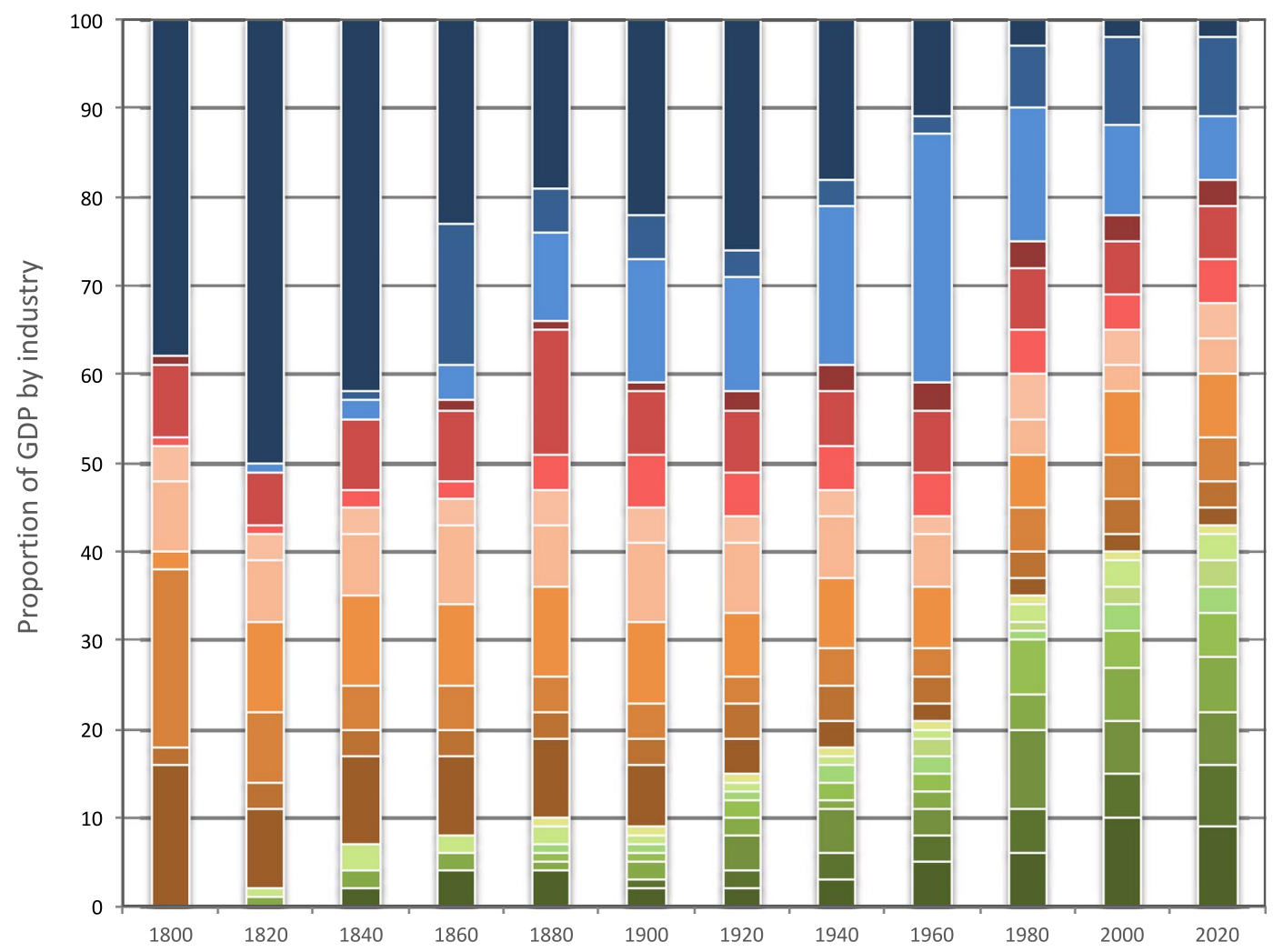

- Agriculture

- Mining

- Manufacturing

- Utilities

- Construction

- Transport, postal

Wholesale trade

- Retail trade

- Dwelling ownership

- Public Admin

- Hospitality

- Personal \& Other Services

Arts \& Recreation

= Rental, Hiring

- Admin Services

Media \& Telecom

Education

- Prof. \& Tech. Services

Ind taxes-subsidies

- Health \& Recreation

- Finance \& Insurance

Fig. 2 Australian industry sectors, actual and projected, 1800-2020, Source: author estimates from Ruthven (2013) 


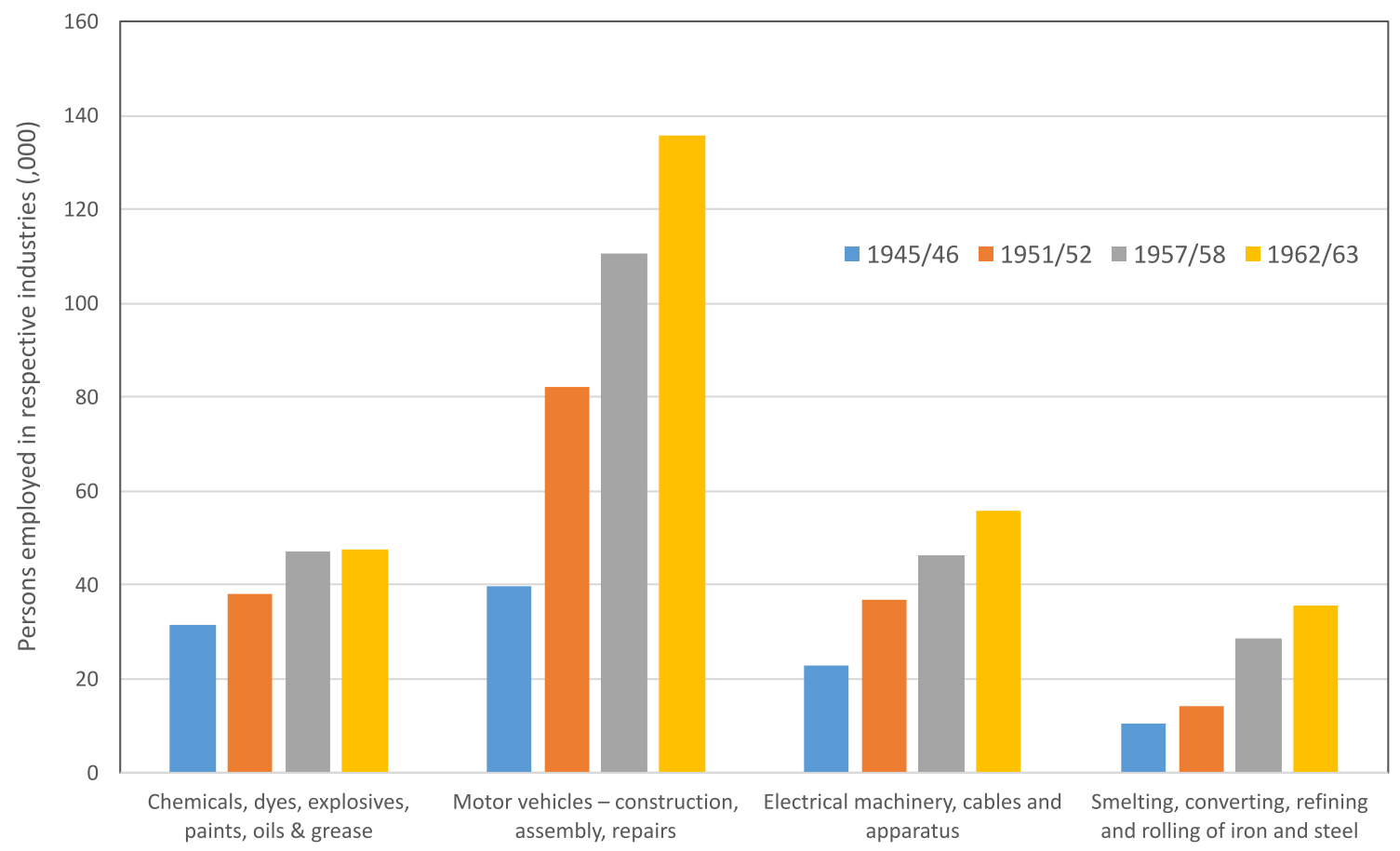

Fig. 3 Persons employed in selected manufacturing industries, post-War. Sources: Australian Bureau of Statistics (ABS) (1955, 1960, 1965)

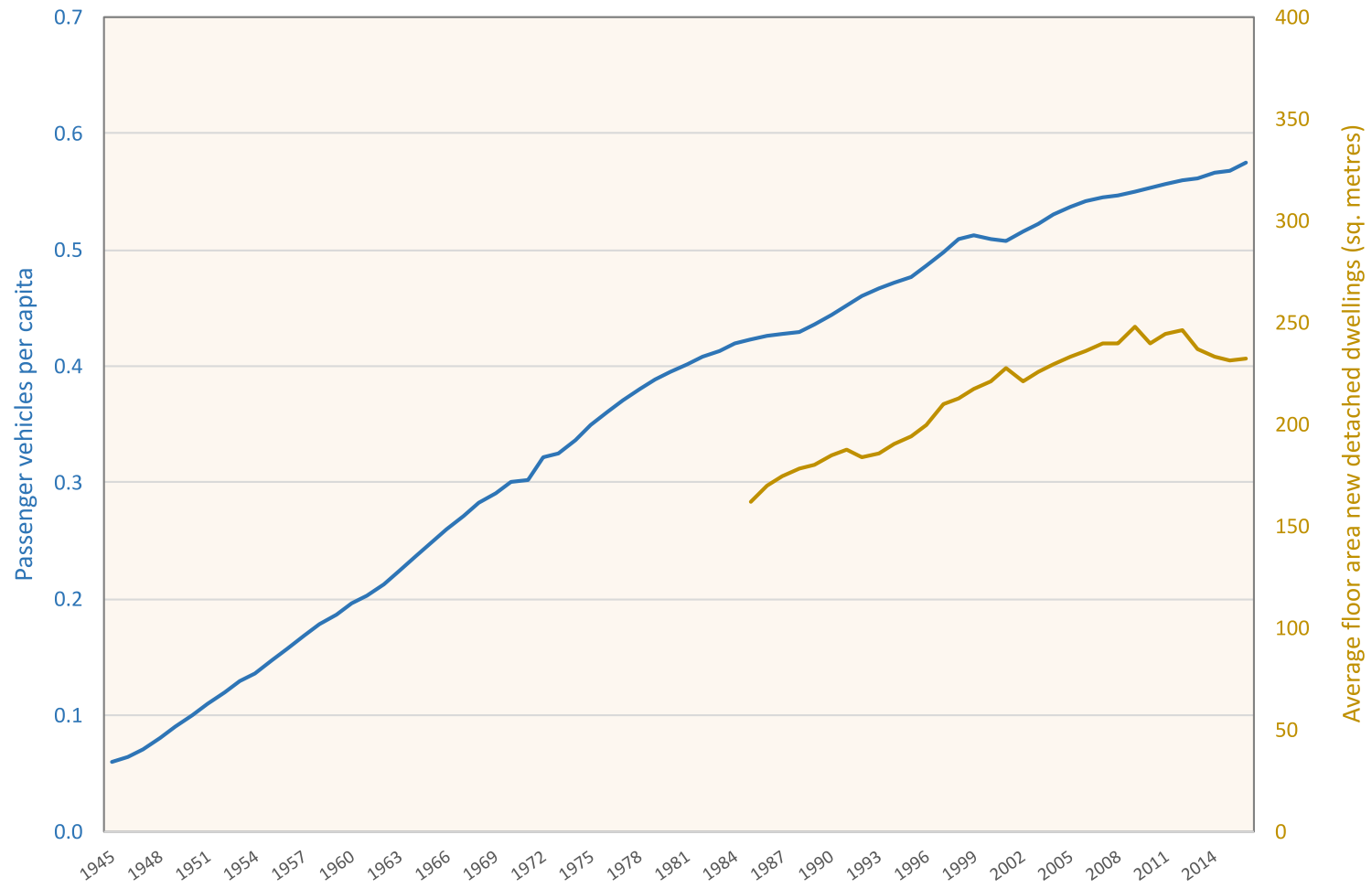

Fig. 4 Passenger vehicles (excluding commercial and other vehicles) per capita 1945-2016, and average floor area of new detached (1962, 1976, 1988, 1999, 2013a, 2014, 2015b); Commsec (2016); dwellings 1984-2016. Sources: Australian Bureau of Statistics (ABS)

Frost and Dingle (1995) 
efficiency, the per capita heating energy consumption in Melbourne remained stable over the studied period of 1960-2010. This was attributed to higher expectations of thermal comfort, such as larger heated areas, extended heating periods and higher thermostat temperatures, and lower per-household occupancy rates.

Since the mid-1990s, per capita energy consumption has plateaued at around 240 GJ per capita per annum. The recent fall in the total consumption for 2013 and 2014 is due to a reduction in the electricity demand as a consequence of a doubling of retail electricity prices during the period 2007-2012, which has mostly impacted coal consumption (Australian Productivity Commission 2013). The price rise has accelerated the recent structural changes, including the closure of energy-intensive production, and a trend towards greater efficiency (Fig. 5). Based on a projected average annual economic growth rate of $2.7 \%$ and using an equilibrium model with ongoing efficiency gains, the growth in primary energy consumption is projected at $1 \%$ per annum for the period up to 2050 (Bureau of Resources and Energy Economics 2014). The BREE projection should be taken as a scenario that satisfies an equilibrium model for a given economic growth rate rather than a forecast.

\section{Real-World End-Use Energy Services}

At face value, the low energy intensity of service sectors and a concentration of wealth in Australian localities associated with ICT services would seem to strengthen the decoupling hypothesis (Ruthven 2012). However, the growth of service sectors and the relative decline of energy-intensive sectors (see Fig. 2) do not seem to have led to strong decoupling. Part of the explanation is that the ongoing demand for the real-world end-use services that consume energy has not diminished. End-use services include passenger and freight transport, construction materials for buildings and other products, food, hygiene, thermal comfort, communications and illumination (Cullen and Allwood 2010). These end-use services are a function of human wants, needs and income. At a global level, a consumption-based approach to energy and material flows (vs. the conventional production approach) shows that the 'material footprint' is still strongly correlated with GDP (Wiedmann et al. 2015).

Furthermore, the 'physical dimensionality' of goods places practical limits on efficiency gains (Bithas and Kalimeris 2013). For example, the fuel economy of motor vehicles is a function of their mass, shape, and required performance. The path dependency of urban development establishes commute distances and the associated energy

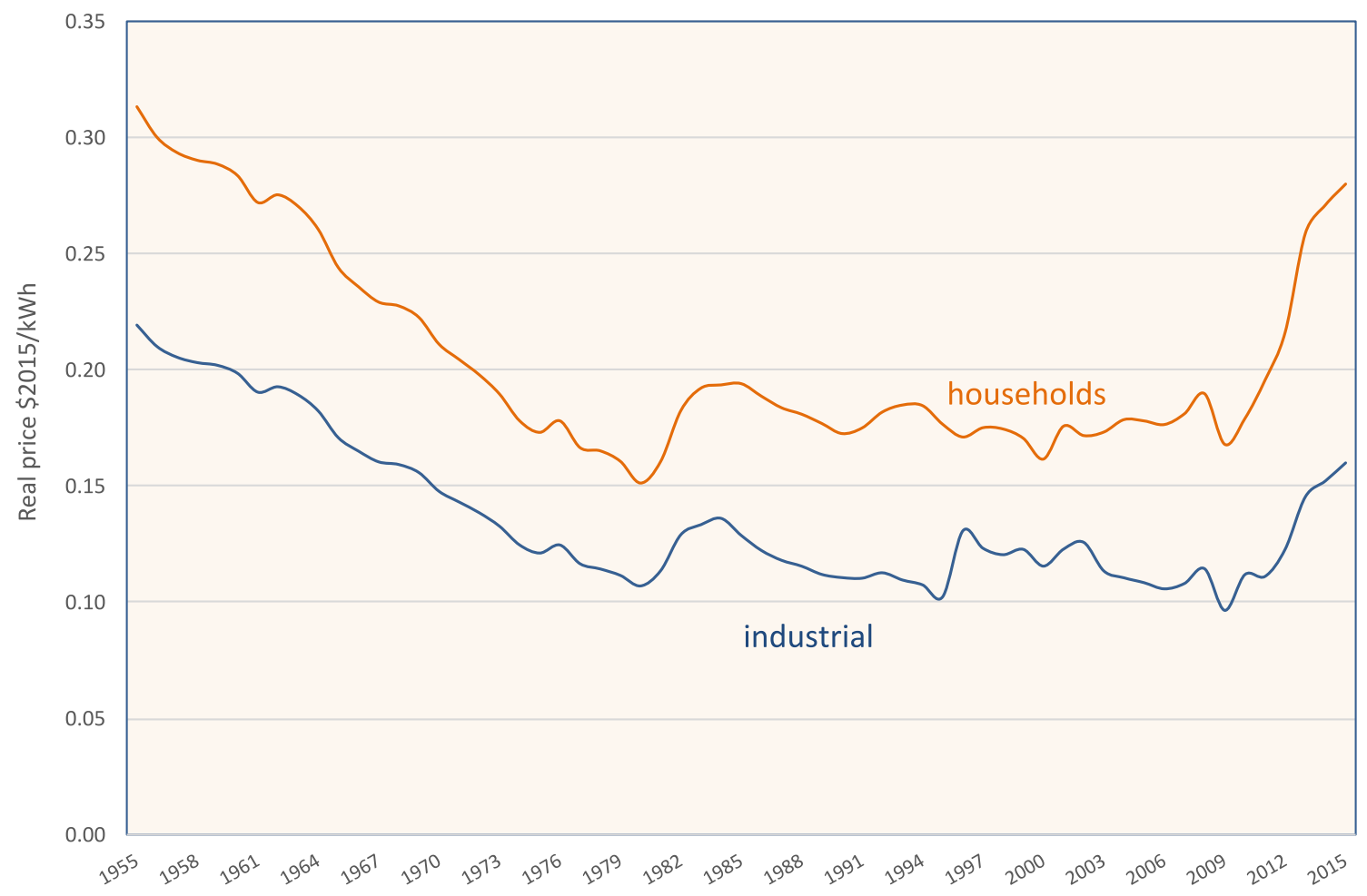

Fig. 5 Real price of electricity (2005AUD) 1955-2015. Calculated from ABS A2325846C CPI index, Australian Bureau of Statistics (ABS) (2016b); Brady (1996); OECDiLibrary (2015) 
footprint. In buildings, people require the full suite of mechanical services, including heating and cooling, lifts and lighting. All of these products and services involve direct and embodied energy consumption. It is not apparent that service and information economies have a fundamentally different need for these services. Indeed, even ICT services are themselves responsible for an expanding and significant magnitude of energy consumption, including the rapid growth of cloud computing and data centres (Aebischer and Hilty 2015, Fig. 7; Corcoran and Andrae 2013).

\section{Unmeasured gains from ICT}

An alternative postulate is that ICT is not significantly contributing to GDP but has led to unmeasured gains in welfare, and therefore material well-being is much higher than that measured by conventional metrics (Brynjolfsson and McAfee 2014). The prime example related to ICT is the claim that social media enhances welfare, but there are many measures of welfare unrelated to economic development, such as relationships and a healthy environment (Australian Bureau of Statistics (ABS) 2013b). If true, this would be equivalent to low energy intensity development, and is sometimes said to explain the so-called 'productivity puzzle' of post-industrial economies.

A resolution to the puzzle is that the recent smartphone developments produce non-market benefits (i.e. consumers are more productive in using their non-market time to consume services they value), but that the impact on conventional standard-of-living metrics is minor (Byrne et al. 2016). In much the same way that the earlier introduction of colour television contributed to unmeasured gains in consumer surplus, social media has supplanted traditional forms of entertainment and communication. From a consumer perspective, social media appears to have zero marginal cost because cellphone and internet services are often fixed monthly cost services. This tends to obscure the costs that lie behind the provision of the services and the telephony infrastructure. Furthermore, social media is not substantially substituting for real-world products such as transport, buildings and food.

\section{Summary}

A key question in sustainability research is whether 'strong' decoupling of energy and resource consumption from economic activity is occurring. An observation supporting the decoupling hypothesis is that national economic activity is increasingly dominated by low energy intensity ICT-driven service sectors-the Australian quaternary and quinary service sectors now comprise 47 and $10 \%$ of the national economy, respectively.

The question was explored by applying a time-series regression between real GDP and primary energy consumption. The regression showed that economic activity and energy consumption has remained linked, but overlaid with distinct long-run trends in energy intensity. Two hypotheses that sought to explain the connection were presented. The first argued that the demand for energy end-use services is a function of human wants, needs and income, irrespective of the relative composition of the national economy. The second argued that ICT-enabled service sectors are driving new business models but not significantly altering the underlying demand for end-use energy services. The deepening of the service economy towards the Infotronics phase should be seen partly as a consequence of sufficient energy supply and productive primary and secondary sectors. The conclusion is that ICT is enabling productivity gains and new business models, but does not significantly weaken the demand for these services, and therefore does not enable strong decoupling.

Acknowledgements The author would like to thank the anonymous reviewers for their valuable comments that substantially improved the commentary.

\section{Compliance with Ethical Standards}

Conflict of Interest The author states that there is no conflict of interest.

\section{References}

Aebischer B, Hilty LM (eds) (2015) 'The energy demand of ICT: a historical perspective and current methodological challenges' ICT Innovations for Sustainability, Springer, Cham, pp. 71-103

Andreessen M. (2011) 'Why Software Is Eating The World'. Wall Str. J. 20:C2

Australian Bureau of Statistics (ABS) (1920) Year book of Australia. ABS, Canberra

Australian Bureau of Statistics (ABS) (1940) Year book of Australia. ABS, Canberra

Australian Bureau of Statistics (ABS) (1955) Year book of Australia. ABS, Canberra

Australian Bureau of Statistics (ABS) (1960) Year book of Australia. ABS, Canberra

Australian Bureau of Statistics (ABS) (1962) Census of motor vehicles. ABS, Canberra

Australian Bureau of Statistics (ABS) (1965) Year book of Australia. ABS, Canberra

Australian Bureau of Statistics (ABS) (1970) Year book of Australia. ABS, Canberra

Australian Bureau of Statistics (ABS) (1976) Census of motor vehicles. ABS, Canberra

Australian Bureau of Statistics (ABS) (1988) Census of motor vehicles. ABS, Canberra

Australian Bureau of Statistics (ABS) (1999) Census of motor vehicles. ABS, Canberra 
Australian Bureau of Statistics (ABS) (2013a) 8752.0 - Building activity, Australia, featured article: Average floor area of new residential dwellings. ABS, Canberra, http://www.abs.gov.au/ AUSSTATS/abs@.nsf/Previousproducts/8752.0FeatureArticle 1 Jun2013

Australian Bureau of Statistics (ABS) (2013b) Measures of Australia's progress-is life in Australia getting better? ABS, Canberra, http://www.abs.gov.au/ausstats/abs@.nsf/mf/1370.0

Australian Bureau of Statistics (ABS) (2014) 3105 - Australian historical population statistics. ABS, Canberra

Australian Bureau of Statistics (ABS) (2015a) 5206.0 - Australian national accounts: National income, expenditure and product series A2304334J. ABS, Canberra

Australian Bureau of Statistics (ABS) (2015b) Census of motor vehicles. ABS, Canberra

Australian Bureau of Statistics (ABS) (2016a) 5209.0.55.001-Australian national accounts: Input-output tables, 2013-14. ABS, Canberra, http://www.abs.gov.au/AUSSTATS/abs@.nsf/Looku p/5209.0.55.001Main+Features12013-14?OpenDocument

Australian Bureau of Statistics (ABS) (2016b) 6401.0 consumer price index - series A2328141J-electricity. ABS, Canberra

Australian Productivity Commission (2013) Electricity network regulatory frameworks report. Australian Productivity Commission, Canberra, http://www.pc.gov.au/inquiries/completed/ electricity/report

Bithas K, Kalimeris P (2013) 'Re-estimating the decoupling effect: Is there an actual transition towards a less energy-intensive economy?' Energy 51:78-84

Brady F (1996) 'Contribution on Australia: A dictionary on electricity', paper presented to the international conference on large high voltage electrical systems. Australia National Committee of CIGRE

Brynjolfsson E, Hitt LM (2000) 'Beyond computation: Information technology, organizational transformation and business performance'. J Econ Perspect 14(4):23-48

Brynjolfsson E, McAfee A (2014) The second machine age: work, progress, and prosperity in a time of brilliant technologies. WW Norton \& Company, New York

Bureau of Infrastructure Transport and Regional Economics (2016) Traffic and congestion cost trends for Australian capital cities. Australian Department of Infrastructure and Regional Development, Canberra, https://bitre.gov.au/publications/2015/files/ is_074.pdf\&gt.

Bureau of Resources and Energy Economics (2014) Australian energy projections to 2049-50. ACT, Canberra

Butlin NG (1962) Australian domestic product, investment and foreign borrowing, 1861-1938/39. Cambridge University Press, Cambridge

Buxton M (2006) Urban form and urban efficiency. Department of the Environment and Energy, Canberra, http://www.environment.gov.au/node/22564

Byrne DM, Fernald JG, Reinsdorf MB (2016) 'Does the United States have a productivity slowdown or a measurement problem?', Brookings Pap Econ Act 2016:109-182

Commsec (2016) US overtakes Australia to build biggest homes CommSec Home Size Trends Report. Commonwealth Bank of Australia, Sydney, https://www.commsec.com.au/content/dam/ EN/ResearchNews/Eco_Insights31.10_US_overtakes_Australia_to_build_biggest_homes.pdf\&gt.

Corcoran P, Andrae A (2013) 'Emerging trends in electricity consumption for consumer ICT'. Rep. NUI Galway Irel 10379:3563

Cramer J, Krueger AB (2016) 'Disruptive Change in the Taxi Business: The Case of Uber', National Bureau of Economic Research, no. 22083.
Cullen JM, Allwood JM (2010) 'The efficient use of energy: Tracing the global flow of energy from fuel to service'. Energy Policy 38(1):75-81

Curry, D (2016), Court records reveal how much revenue and profit Google has made from Android, Digital Trends, http://www.digitaltrends.com/mobile/google-android-revenue-revealed/. Viewed 10 March 2016

Deloitte Access Economics (2016) Economic effects of ridesharing in Australia. Deloitte Access Economics, Sydney, https://www2. deloitte.com/content/dam/Deloitte/au/Documents/Economics/deloitte-au-economic-effects-ridesharing-australia-010216. pdf\&gt.

Dyster B, Meredith D (1990) Australia in the International Economy: in the twentieth century, CUP Archive. Cambridge University Press, New York

Edwards JB, McKinnon AC, Cullinane SL (2010) 'Comparative analysis of the carbon footprints of conventional and online retailing A "last mile" perspective'. Int J Phys Distrib Logistics Manag 40(1/2):103-123

Energy Information Agency (EIA) (2015) Passenger travel accounts for most of world transportation energy use. EIA, Washington D.C., https://www.eia.gov/todayinenergy/detail. php?id=23832\&gt.

Frost L, Dingle T (1995) 'Sustaining suburbia: An historical perspective on Australia's urban growth'. In: Troy PN (ed) Australian Cities: Issues, strategies and policies for urban Australia in the 1990s, 1st edn. Cambridge University press, Cambridge, p 20

Fuller RB (1973) Nine chains to the moon. Cape, London

Kurzweil R (1999) The age of spiritual machines: When computers exceed human intelligence. Penguin, New York

Lee $T$ (2011) The Great Ephemeralization. http://timothyblee. com/2011/04/26/the-great-ephemeralization/.

Magner L (2016a) Fast fashion in Australia. IBIS World, Melbourne

Magner L (2016b) Online women's clothing sales in Australia. IBIS World, Melbourne

Modahl IS, Raadal HL, Gagnon L, Bakken TH (2013) 'How methodological issues affect the energy indicator results for different electricity generation technologies'. Energy Policy 63:283-299

Mokhtarian P (2009) 'If telecommunication is such a good substitute for travel, why does congestion continue to get worse?' Transp Lett 1(1):1-17

Moody's (2016) Continued hotel construction a greater threat to US lodging sector CMBS than Airbnb, Moody's Investor Services, Boston, https://www.moodys.com/research/MoodysContinued-hotel-construction-a-greater-threat-to-US-lodgingPR_345701\&gt.

OECDiLibrary (2015) Dataset: OECD - Electricity/heat supply and consumption. http://stats.oecd.org/OECDStat_Metadata/ShowMetadata.ashx? ? Dataset=ELE_BALANCE\&ShowOnWeb $=$ true $\&$ Lang=en.

Office of the Chief Economist (2015) Table B1 - Australia population, GDP and energy consumption. http://www.industry.gov. au/Office-of-the-Chief-Economist/Publications/Documents/aes/ data/2015/Table-B.xlsx. Viewed 25 August 2016

Palmer G (2012) 'Does energy efficiency reduce emissions and peak demand? A case study of 50 years of space heating in Melbourne'. Sustainability 4(7):1525-1560

Ruthven P (2012) A snapshot of Australia's digital future to 2050. IBIS World, Melbourne, http://www-07.ibm.com/au/pdf/1206_ AustDigitalFuture_A4_FINALonline.pdf

Ruthven P (2013) The Phenomenon of Industry Cycles. IBIS World, Melbourne, http://www.ibisworld.com.au/common/pdf/phil/ Phil_April_2013_FINAL.pdf

Schor J (2016) 'Debating the sharing economy'. J Self-Gov Manage Econ 4(3):7-22 
Smil V (2013) Making the modern world: Materials and dematerialization. John Wiley \& Sons, Chicester

Stanwix G, Pham P, Ball A (2015) End-use energy intensity in Australia. Office of the Chief Economist, Canberra

Tainter J (1990) The collapse of complex societies. Cambridge University Press, Cambridge

Vamplew W (1987) Australians: a historical library. v10: Australians: historical statistics. vol 10, Syme \& Weldon, Fairfax

Van Wee B, Geurs K \& Chorus C (2013) 'Information, communication, travel behavior and accessibility'. J Transp L Use 6:1-16
Wiedmann TO, Schandl H, Lenzen M, Moran D, Suh S, West J, Kanemoto K (2015) 'The material footprint of nations'. Proc Natl Acad Sci 112(20):6271-6276

Zhou C, Robb K (2016) Shopping centre redevelopments are putting suburbs back on the map. domain.com.au, Sydney, https://www. domain.com.au/news/shopping-centre-redevelopments-are-putting-suburbs-back-on-the-map-20161025-gsa64f/\&gt. 